\title{
Local Development Fee in Slovak Republic
}

\author{
Jarmila Hudakova \\ Constantine the Philosopher University in Nitra, Slovak Republic
}

\begin{abstract}
With the advent of tax and expenditure limitations, state and local governments have been searching for new sources of revenue to maintain or expand public services. The need for new sources of revenue has been particularly acute in localities that have experienced rapid growth. The new act No. 447 of November 20, 2015 on Local Development Fee was approved in Slovakia. The Act comes into force on November 1, 2016. The paper points out possible problems associated with the introduction of the local development fee abroad and discribes the situation in Slovakia.
\end{abstract}

Keywords: local development fee, tax incidence, local government, local policy, infrastructure financing

\section{Introduction}

Local development fee (hereinafter only the "development fee") is one time charge applied to new developments. Its goal is to raise revenue for the construction or expansion of capital facilities. Development fee is designed to transfer a portion of the capital cost for new infrastructure from the public to the private sector. Its specific purpose is to ensure that new development pays its own way, alleviating the burden that would otherwise fall to existing property owners. Fees will be required of builders and developers to help pay, for example, water and sewer systems, streets and street lighting, drainage systems, and parks or green space. Thus, part of the infrastructure or services normally provided by the local government is funded by the developer rather than by general revenue. Slovak Republic has enacted legislation authorizing the local government to adopt local development fee.

\section{Legal Issues}

Slovak National Council enacted the Act No. 447 of November 20, 2015 on local development fee. This Act comes into force on November 1, 2016. This Act enacts local development fee. The development fee can be established by a municipality in its territory, a separate part thereof or a separate cadastral area, by the generally binding regulation. Subject to development fee are land buildings in the territory of the municipality, for which a valid building permit has been issued to permit the construction. In the Act, there are some points which are not subject to development fee, for example, elimination of defects or a building or in serious disrepair of a building, construction of a family house with floor less than $150 \mathrm{~m}^{2}$, social housing, a healthcare facility, building use as schools, and so on. The liability to pay commences on the final validity date of the building

\footnotetext{
Jarmila Hudáková, Ph.D., M.B.A., Assistant Professor, Faculty of Natural Sciences, Institute of Economics and Management, Constantine the Philosopher University in Nitra.

Correspondence concerning this article should be addressed to Jarmila Hudáková, Constantine the Philosopher University in Nitra, Faculty of Natural Sciences, Institute of Economics and Management, Tr. A. Hlinku1, 94901 Nitra, Slovak Republic. Email: jhudakova@ukf.sk; Mobile: +421905441118.
} 
permit. The payer is a natural person or a legal entity in a position of a developer for whom a building permit has been issued except municipalities, self-governing regions or the state. The base of the development fee is the floor area of the above-ground part of the building in $\mathrm{m}^{2}$. The development fee rate ranks from EUR 10 to EUR 35 per each $\mathrm{m}^{2}$ or a part thereof, of the floor area of the above-ground part of the building. A municipality can set development fee rates for various buildings in the breakdown by act. A municipality can set or change the development fee rate by a generally binding regulation only as at January 1 of a calendar year. The development fee is an income to the budget of the municipality. The income from the development fee can be used for payment of capital expense related to the building, including settlement of land for that purpose: childcare facilities, buildings used for provision of social, sporting and cultural services, social housing, school facilities and vocational training facilities, healthcare facilities, publically accessible parks, landscaping, local roads, parking spaces and technical infrastructure (Act No. 447/2015).

\section{The Theory of the Incidence of Impact Fees}

The theoretical literature on the incidence of impact fees can be divided into an old view (Altshuler \& Gómez-Ibánez, 1993; Delaney \& Smith, 1989a; 1989b; Downing \& McCaleb, 1987; Snyder, Stegman, \& Moreau, 1986; Huffman, Nelson, Smith, \& Stegman, 1988; Singell \& Lillydahl, 1990) and a new view (Yinger, 1998a). The old view treats impact fees as an excise tax on developers, ignoring the new public capital services (or infrastructure) that are financed by the fees. Hence, under the old view, the imposition of an impact fee in a competitive market results in the standard short-run excise tax effect: the supply of new housing shifts up by the amount of the fee, resulting in a higher price paid by new homebuyers, a lower net price received by developers, and a lower quantity of new homes built. An underlying assumption of the old view is that the demand for housing is not perfectly elastic. Based on the assumption that supply and demand are neither perfectly elastic nor perfectly inelastic, the old view predicts that the increase in the price of new homes and the decline in the net price received by developers will both be less than the amount of the fee. In the short-run, therefore, both the new homebuyer and the developer share the burden of the fee-the new homebuyer in the form of a higher price and the developer in the form of economic losses. Because new and existing housing are close but imperfect substitutes, the old view also predicts that impact fees will cause some homebuyers who otherwise would have purchased a new home to instead buy an existing home. This shift in demand in favor of existing homes will increase their price by something less than the increase in the price of new homes. In the long run, developers' profits return to a normal level as their bids for land decline, resulting in reductions in the price of land. Thus, part of the burden of the impact fee is shifted backward to landowners. Huffman et al. (1988), however, argued that backward shifting is highly unlikely because landowners have a reservation price below which they will not sell, and they will keep their land off the market until prices rise to that level. This argument is not persuasive. While the existence of a reservation price may make land prices sticky in a downward direction in the short run, it does not eliminate the possibility that impact fees will be shifted backward. In a depressed market with reduced housing construction, reservation prices eventually decline in the absence of buyers.

The chief differences between the old and new view theories of impact fee incidence are that the new view incorporates the public capital services that are financed by the fees, recognizes the impact of property tax capitalization on the incidence of the fees, and assumes that the housing demand curve facing construction firms in a single jurisdiction is horizontal. The latter assumption is equivalent to assuming that new 
homebuyers are mobile. Yinger (1998b) argued that the old view's reliance on downward-sloping demand rests upon faulty reasoning: However, the motivation for downward-sloping demand in the literature is not clear. In particular, most of the articles in the literature argue that demand will slope downward in a community that has non-reproducable characteristics or no close substitutes. With mobile households, however, the value of non-reproducable characteristics will simply be capitalized into the price of housing-with no impact on the slope of the demand curve. While impact fees are not shifted forward to new homebuyers under the new view, the benefits that accrue to new homebuyers from the infrastructure financed from the fee are capitalized into new home prices. If the increase in price that results from the capitalization of benefits equals the fee, then neither the developer nor the landowner bear any burden of the fee since developers' profits remain at the normal level. The fee is borne by the homebuyer in the form of a higher housing price, but net of the benefits received from the fee-financed infrastructure there is no burden. However, if these benefits are less valued by the new homebuyer and therefore result in a house price increase that is less than the fee, restoration of developers' profits to a normal level requires that the price of land declines. On the other hand, if the benefits from the new infrastructure are highly valued by new homebuyers and as a result the increase in the price of housing exceeds the amount of the impact fee, then normal profits for developers require an increase in the price of land. Land prices therefore remain unchanged, decrease, or increase depending upon whether the benefits of the new infrastructure are equal to, less than, or greater than its costs, assuming that these costs are fully covered by the impact fees. The above effects assume no change in the property tax rate. However, the increase in house values due to the infrastructure improvements raises the property tax base in the jurisdiction and increases the revenue that can be raised at the old tax rate.

The property tax is not directly linked to the value of the property in Slovakia yet.

\section{Pros and Cons}

The municipality can decide whether or not the development fee establishes in its territory by a generally binding regulation. It is important to know the pros and cons of this step. The greatest pro of exactions is that they allow local governments to assess to development a larger portion of the real costs that the development imposes on the community. The greatest con is the local resistance to such measures, often coming from politically-active interests related to development. This can create a substantial problem at the local level since growth and development represent a major part of the economy for many local governments. Below is an overview of authors who deal with the issue.

Bunnell (1994), in his article, stated that proponents argue that development fees "make developers pay" for the costs their developments impose on communities. This can be a politically popular argument. But the cost of development fees is rarely paid by developers. In areas with strong property markets, the fee will almost always be passed on to the next occupant in the form of a higher purchase price or increased rent. The second possibility is that the developer, knowing that the fee has to be paid, will pay the landowner less for the land. The least likely possibility is that the fee will be paid by the developer. Developer needs a certain level of profit for a project to make sense, given the risks involved. If the development fee cannot be passed back to the landowner, or forward to the purchaser, the developer very likely will not go forward with the project. Most empirical studies to date have found that the cost of impact fees is passed on to new residents in the form of higher home prices. This finding is not surprising for two reasons. First, as a practical matter, development fees are usually imposed in communities with strong real estate markets, in which the costs of the fees are most able 
to be passed on in the form of higher prices. Second, impact fees generally pay for improvements which make new developments more desirable, functionally and/or aesthetically, and therefore more valuable in terms of the market price they can command. Another problem, communities which are stagnating or declining will be unable to collect such charges because developers do not want to develop there in the first place, and will be even less likely to do so if an additional charge is imposed. At the end, development fees may be imposed by communities not so much to pay for growth as to discourage new development, and make new development more expensive. Existing property owners often have a powerful incentive to impose development fees, since increasing the scarcity and cost of new housing makes existing homes and developed properties more valuable.

Yuen (2008) in his paper also indicated some problems. It is not so obvious who ultimately bears the cost. When a developer builds homes, even though the developer actually pays the fees when getting the building permits, it is not clear whether the developer bears the cost in the end, accepting a lower profit. It is possible that the developer passes the cost on to the home buyer, or that the developer will offer less when buying land on which to build a project. If you think of the homebuilding process as involving three main players: the owner of the raw land, who sells it to the developer, who builds the homes, and sells them to the home purchaser, the impact fee can conceivably be absorbed by any of these three, or by a combination of all three. If the impact fee is ultimately passed on to the home buyer, it then becomes part of the purchase price and typically is financed within the mortgage. At a $6.25 \%$ mortgage, over 30 years, a $\$ 6,387$ impact fee would cost the buyer about $\$ 38 /$ month (study example of Hawaii).

Ihlanfeldt and Shaughnessy (2004) presented the results from estimating the effects of development impact fees on the prices of new and existing single-family homes and undeveloped residential land using unique data for Dade County, FL. Dade County encompasses the entirety of the Miami, Florida Primary Metropolitan Statistical Area. Dade County along with Broward County forms the Miami-Ft. Lauderdale Consolidated Metropolitan Statistical Area. Their results provide no support for the argument that development fees reduce homeownership affordability. Development fees have also been praised as an effective anti-sprawl policy. Their results suggest that the rate at which agricultural land is converted to residential use is slowed by impact fees. By reducing the price of vacant residential land, impact fees lower the opportunity cost of continuing to use land for agricultural purposes, causing land to be held for a longer period in agricultural use.

\section{Evidence from Slovakia}

Opponents of the development fee argue that this fee will slow down the construction of family houses. However, the family house with floor less than $150 \mathrm{~m}^{2}$ is not subject to development fee. Already in 2013, a survey showed that Slovaks build smaller houses. It found the survey of company Economics Construction, which for its on representative sample of Slovak and Czech population prepared research agency Perfect Crowd. Family house in Slovakia, since 1998, shrunk on average by half. While 15 years ago in Slovakia built houses which had an average of $250 \mathrm{~m}^{2}$, today it is $90-110 \mathrm{~m}^{2}$. Sixty six percent of the respondents in Slovakia mentioned in the survey living area of $90-110 \mathrm{~m}^{2}$. This means that the development fee will not significantly affect the development of the construction of family houses.

The top benefits of development fee include:

(1) Assessment around the new construction (playgrounds, parks, kindergartens, infrastructure);

(2) Enhancing the quality of life of residents in the area;

(3) Credit enhancement properties in the area; 
(4) Improved coordination of infrastructure construction between builder and self-government;

(5) Reduction of corruption and clientelism.

The development fee will have a particular impact on developers. It must be said that despite the absence of law until today, reputable developers cooperate with municipality in its territory and understand the need to contribute to infrastructure development. Projects that annually transmit developers, for example, to Bratislava Magistrate, or district, have today reached a value of millions euros.

Some municipalities already published proposal for a general binding municipal regulation of local development fee (see Table 1).

Table 1

Development Fee Rate in Some Municipalities in $€$

\begin{tabular}{llllll}
\hline Type of buildings/municipalities & Pezinok & Bernolákovo & Chorvátsky Grob & Jasenica & Dubova \\
\hline Residential buildings & 35 & 10 & 35 & 35 & 10 \\
Buildings used for agricultural production & 25 & 10 & 35 & 20 & 15 \\
Industrial buildings & 35 & 30 & 35 & 35 & 18 \\
Buildings use for other business & 35 & 15 & 35 & 35 & 18 \\
Other buildings & 35 & 10 & 35 & 20 & 13 \\
\hline
\end{tabular}

Note. Source: General binding municipal regulations (Retrieved from http://www.pezinok.sk/, http://www.bernolakova.sk/, http://www.chorvatskygrob.sk/, http://www.jasenica.sk/, http://dubova.sk/).

Some municipalities have used the highest rate such as Chorvátky Grob, Pezinok (except buildings for agricultural production). Municipality Jasenica has used also different rates for external and internal territory cadastral municipality. We can see in Table 1 the rate for external territory. Rates for internal territory are lower. Residential buildings $5 € / \mathrm{m}^{2}$, buildings used for agricultural production $0 €$, industrial buildings $15 €$, buildings use for other business $15 €$ and other buildings $0 €$.

City District Bratislava - Záhorská Bystrica has published data on the number of building permits issued and agreements on cooperation in the construction and development (see Table 2).

Table 2

Overview of the Number of Building Permits and Agreements on Cooperation in the Construction and Development

\begin{tabular}{lccc}
\hline Year & Number of building permits & Number of concluded contracts & Amount of contributions paid \\
\hline 2010 & 112 & 25 & 154,500 \\
2011 & 110 & 34 & 80,500 \\
2012 & 93 & 40 & 142,700 \\
2013 & 81 & 34 & 67,500 \\
2014 & 119 & 56 & 107,000 \\
Total & 515 & 189 & 552,200 \\
\hline
\end{tabular}

Note. Source: http://www.zahorskabystrica.sk/category/mestska-cast/uradna-tabula.

We can see that reputable developers cooperate with municipality in its territory and pay development fee without valid law. We can assume that if all developers have to pay development fee, municipality will get more money to develop the necessary infrastructure.

Example: The estimate of revenue for the city to 100,000 inhabitants. On average, it was in this city in the years 2012-2016 completed: 
(1) $120,000 \mathrm{~m}^{2}$ utility area for living;

(2) $6,000 \mathrm{~m}^{2}$ facilities for administration;

(3) $250,000 \mathrm{~m}^{2}$ other buildings.

At the uniform rate of income for five years the turnover could be:

(1) At least (10 €): 3,760,000 € (it means 752,000 € per year);

(2) Maximum (35 €): 13,160,000 € (it means 2,632,000 € per year).

This money could be used, for example, for $50,000-185,500 \mathrm{~km}^{2}$ of roads or footpaths or parking lots, or for $182,800-639,800 \mathrm{~m}^{2}$ playgrounds or parks.

Despite increased revenues for city budget, the municipality still became afraid to introduce local development fee.

\section{Conclusion}

Today there are no rules to support the development by the developers. In our view, it should be clear in advance which town/city plans development, where it will build on what conditions, including the development fee. An investor will know conditions because it is possible to read in generally binding regulation as required by law. It will reduce corruption. Amount of the fee does not cover expenditure on investment related to new construction. It is negligible percentage of the price of the apartment or house or the actual cost of complex infrastructure in the construction of new localities. Development fee is a contribution to higher quality living environment in towns and villages. The development fee rate ranks from EUR 10 to EUR 35 per each $\mathrm{m}^{2}$ or a part thereof, of the floor area of the above-ground part of the building. A municipality can set development fee rates for various buildings in the breakdown by act.

\section{References}

Altshuler, A. A., \& Gómez-Ibánez, J. A. (1993). Regulation for revenue: The political economy of land use exactions. Washington, DC: The Brookings Institution.

Bunnell, G. (1994). Pros and cons of paying for growth with impact fees. A Newsletter of Department of Agricultural Economics, University of Wisconsin-Madison and Community, Natural Resource and Economic Development Programs. Number 207.

Delaney, C. J., \& Smith, M. T. (1989a). Impact fees and the price of new housing: An empirical study. American Real Estate and Urban Economics Association Journal, 17(1), 41-54.

Delaney, C. J., \& Smith, M. T. (1989b). Pricing implications of development exactions on existing housing stock. Growth and Change, 20(4), 1-12.

Downing, P. B., \& McCaleb, T. S. (1987). The economics of development exactions. In J. E. Frank, \& R. M. Rhodes (Eds.), Development exactions (pp. 42-69). Washington DC: Planners Press.

Huffman, F. E., Nelson, A. C., Smith, M. T., \& Stegman, M. A. (1988). Who bears the burden of development impact fees? Journal of the American Planning Association, 54(1), 49-55.

Ihlanfeldt, R. K., \& Shaughnessy, T. M. (2004). An empirical investigation of the effects of impact fees on housing and land markets. Regional Science and Urban Economics, 34(6), 639-661.

Singell, L. D., \& Lillydahl, J. H. (1990). An empirical examination of the effect of impact fees on the housing market. Land Economics, 66(1), 82-92.

Snyder, T. P., Stegman, M. A., \& Moreau, D. H. (1986). Paying for growth: Using development fees to finance infrastructure. Washington, DC: Urban Land Institute.

Yinger, J. (1998a). Who pays development fees? In H. F. Ladd, \& W. E. Oates (Eds.), Local government tax and land use policies in the United States: Understanding the links. Northampton, MA: Edward Elgar.

Yinger, J. (1998b). The incidence of development fees and special assessments. National Tax Journal, 51(1), 23-41.

Yuen, C. (2008). Bill 324 Impact Fees. County Council Hawaii. 